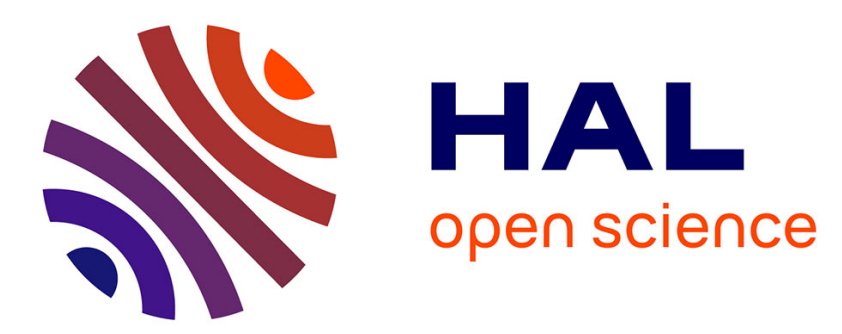

\title{
Role of aromatic substituents on the antiproliferative effects of diphenyl ferrocenyl butene compounds
}

Ouardia Zekri, Elisabeth A. Hillard, Siden Top, Anne Vessières, Pascal

Pigeon, Marie-Aude Plamont, Michel M. Huché, Sultana Boutamine, Michael

J. M.J. Mcglinchey, Helge Muller-Benz, et al.

\section{To cite this version:}

Ouardia Zekri, Elisabeth A. Hillard, Siden Top, Anne Vessières, Pascal Pigeon, et al.. Role of aromatic substituents on the antiproliferative effects of diphenyl ferrocenyl butene compounds. Dalton Transactions, 2009, 22, pp.4318-4326. 10.1039/B819812H . hal-00449003

\section{HAL Id: hal-00449003 https://hal.science/hal-00449003}

Submitted on 10 May 2021

HAL is a multi-disciplinary open access archive for the deposit and dissemination of scientific research documents, whether they are published or not. The documents may come from teaching and research institutions in France or abroad, or from public or private research centers.
L'archive ouverte pluridisciplinaire HAL, est destinée au dépôt et à la diffusion de documents scientifiques de niveau recherche, publiés ou non, émanant des établissements d'enseignement et de recherche français ou étrangers, des laboratoires publics ou privés. 


\title{
Role of aromatic substituents on the antiproliferative effects of diphenyl ferrocenyl butene compounds $\uparrow$
}

\author{
Ouardia Zekri, ${ }^{\text {a,b }}$ Elizabeth A. Hillard, ${ }^{a}$ Siden Top, ${ }^{a}$ Anne Vessières, ${ }^{a}$ Pascal Pigeon, ${ }^{a}$ Marie- \\ Aude Plamont, ${ }^{a}$ Michel Huché, ${ }^{a}$ Sultana Boutamine, ${ }^{\mathrm{b}}$ Michael J. McGlinchey, ${ }^{\mathrm{c}}$ Helge Müller- \\ Bunz $^{\mathrm{c}}$ and Gérard Jaouen ${ }^{* a}$
}

\footnotetext{
${ }^{a}$ Laboratoire Charles Friedel, UMR CNRS 7223, Ecole Nationale Supérieure de Chimie de Paris, 11, rue Pierre et Marie Curie, 75231, Paris Cedex 05, France

${ }^{\mathrm{b}}$ Université des Sciences et de la Technologie Houari Boumediene, BP 32, El Alia Bab Ezzouar, Alger, Algeria

${ }^{\mathrm{c}}$ UCD School of Chemistry and Chemical Biology, University College Dublin, Belfield, Dublin 4, Ireland
}

We have been exploring the cytotoxic effects of conjugated phenylferrocene systems on breast cancer cells. Complexes with $p-\mathrm{OH}, p-\mathrm{NH}_{2}$, and $p-\mathrm{NHC}(\mathrm{O}) \mathrm{CH}_{3}$ substitution show particularly high activity, with $\mathrm{IC}_{50}$ values in the low or sub micromolar range for both the hormone-dependent MCF-7 and hormone-independent MDA-MB-231 breast cancer cell lines. We now present the synthesis, X-ray crystal structures and biochemical studies of analogous halogen or pseudo-halogen para-substituted compounds with $\mathrm{R}=\mathrm{Cl}$, (Z)-7a; $\mathrm{Br}$, $(Z)-7 \mathbf{b} ; \mathrm{CF}_{3},(E)-\mathbf{7 c}$; and $\mathrm{CN},(E)-\mathbf{7 d}$ and $(Z)-7 \mathbf{d}$. Lacking hydrogen bonding groups, the compounds have low, but non-zero, relative binding affinity values for the oestrogen receptor alpha (RBA $\leq 0.55 \%)$ as well as mildly exothermic ligand binding in in silico ER docking experiments. All compounds show estrogenic (proliferative) activity on the MCF-7 cell line. On MDA-MB-231 cells, the cyano complex (Z)-7d shows a reasonable cytotoxic effect $\left(\mathrm{IC}_{50}=11 \mu \mathrm{M}\right)$, its isomer $(E)-7 \mathbf{d}$ is only slightly cytotoxic $\left(\mathrm{IC}_{50}=60 \mu \mathrm{M}\right)$, while the $\mathrm{Cl}, \mathrm{Br}$, and $\mathrm{CF}_{3}$ derivatives have no effect. Cytotoxic properties, while they correlate somewhat with the resonance donating abilities of the substituent, are more strongly dependent on the presence of a proton in the functional group, supporting our prior proposition that electrophilic quinoid forms of the compounds could be active species in the cell. A correlation of the redox potential of the ferrocenyl moiety with the Hammett-Taft constants of the substituents was observed. 


\section{Introduction}

With the notable exception of a few ruthenium complexes, ${ }^{1,2}$ the anticancer properties of most metal-containing drugs or drug leads are attributable to their direct interaction with DNA, such as observed in the cisplatin series. ${ }^{3} \mathrm{We}$ are currently developing a new class of cytostatic organometallic compounds, which seem to engage in a non-genomic pathway, ${ }^{4}$ which could have implications for presently incurable cancers and for drug resistance problems. These compounds are based on polyphenols, which are dramatically activated by the introduction of the redox-active ferrocenyl group. ${ }^{5}$ For example, the organic dihydroxy-1,1,2triphenylbutene, 1 (chart 1), causes proliferation of breast cancer cells associated with an estrogenic effect, while replacement of the 2-phenyl substituent by a ferrocenyl moiety, as in 2, induces an additional powerful anti-proliferative (cytotoxic) effect, even on hormone independent cells (MDA-MB-231). ${ }^{5}$ Neither ferrocene itself, nor typical organic polyphenols, are toxic against MDA-MB-231 cells in this low or sub micromolar range, and it should be emphasized that the simple presence of a ferrocenyl group on an organic molecule is not always sufficient to yield cytotoxic compounds. ${ }^{6}$ Compounds possessing a ferrocenyl group tethered to a $p$-phenol via a conjugated system, such as $\mathbf{2}$ or $\mathbf{3}$, have been found to be strongly toxic against cancer cells. ${ }^{4,7-11}$ This can be explained by the role that ferrocene plays as a "redox antenna", which appears to favour the generation of the electrophilic quinone methide species, $\mathbf{4}$, in cancer cells and can lead, via interaction with nucleophiles, to cell death. ${ }^{12}$ Therefore, modification of non-toxic polyphenols with an equally non-toxic organometallic moiety completely changes the cytotoxicity scale of such molecules, and demonstrates a case where the whole is greater than the sum of its parts. ${ }^{13}$
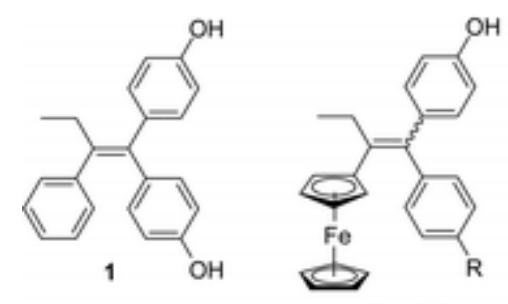

2: $\mathrm{R}=\mathrm{OH}$ $3: R=H$

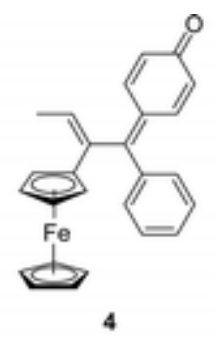

Chart 1

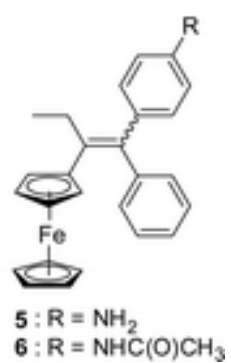

6: $\mathrm{R}=\mathrm{NHC}(\mathrm{O}) \mathrm{CH}_{3}$ 
The role played by the acidity of the phenol group is essential to obtain a species such as 4 . However, other compounds possessing protic groups, such as the aniline $\mathbf{5}$ and acetamide $\mathbf{6}$, are also strongly cytotoxic $\left(\mathrm{IC}_{50}<1 \mu \mathrm{M}\right)$ against hormone-independent breast cancer cells, and appear to follow a similar mechanism. ${ }^{14}$ We now have extended our study to include halogens and pseudo-halogen substituents, to determine if any correlation between their Hammett-Taft values ${ }^{15,16}$ and their antiproliferative properties can be ascertained. We report here the synthesis, characterisation, receptor binding, and cell culture results for a series of compounds based on the 2-ferrocenyl-1,1-diphenyl-but-1-ene skeleton, with varying aromatic substituents $\left(\mathrm{R}=\mathrm{Cl}, \mathrm{Br}, \mathrm{CF}_{3}\right.$ and $\left.\mathrm{CN}\right)$.

\section{Results}

\subsection{Synthesis}

We have prepared four new ferrocenyl complexes (7a-7d) with halogen or pseudo halogen substituents on one of the phenyl rings of 2-ferrocenyl-1,1-diphenyl-but-1-ene. The substituents on the arene have been placed in the para position, because this site tends to favour antiproliferative effects. ${ }^{7}$ The synthesis of compounds $\mathbf{7 a}-\mathbf{c}$ is essentially based on the McMurry cross-coupling method, which consists in the coupling of two ketones in the presence of a mixture of $\mathrm{TiCl}_{4}$ and zinc, and is useful in obtaining unsymmetrical alkenes. This reaction theoretically yields three alkenes, two symmetrical homo-coupled products, and the desired unsymmetrical cross-coupled product. ${ }^{17-19}$ However, it has been shown that when one of the ketones is benzophenone, the unsymmetrically coupled product is favored. ${ }^{20,21}$

Ferrocenyl complexes 7a-c (Scheme 1) were obtained as a mixture of the $Z$ and $E$ isomers and were purified by preparative HPLC. These isomers cannot be separated by HPLC and their proportion was calculated from the NMR spectra of the mixture. However, fractional crystallisation of the mixtures eventually yielded pure isomers $(Z)-\mathbf{7 a},(Z)-\mathbf{7 b},(E)-\mathbf{7} \mathbf{c}$ the structures of which were determined by X-ray crystallography. 


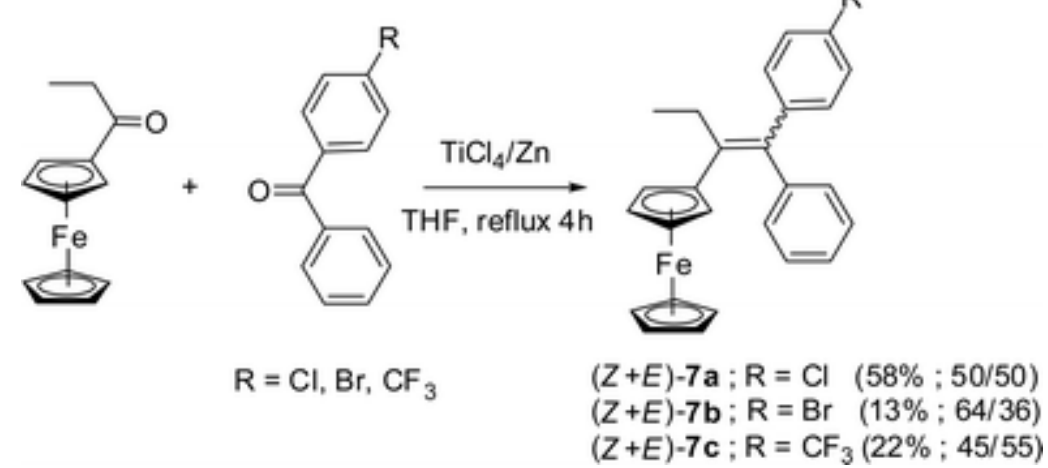

Scheme 1 Synthesis of the ferrocenyl derivatives $7 \mathbf{a}-\mathbf{c}$ (in brackets are the yields and ratios of the $Z$ and $E$ isomers).

$(Z+E)-7 \mathbf{d}$ (Scheme 2) was obtained by heating the bromo derivative $(Z+E)-\mathbf{7 b}$ with $\mathrm{CuCN}$ in DMF for $12 \mathrm{~h}$; the chloro derivative 7a did not react with $\mathrm{CuCN}$ under the same conditions. This time the separation of the $Z$ and $E$ isomers could be accomplished by HPLC, and both (Z)- and (E)-7d were identified by X-ray diffraction.
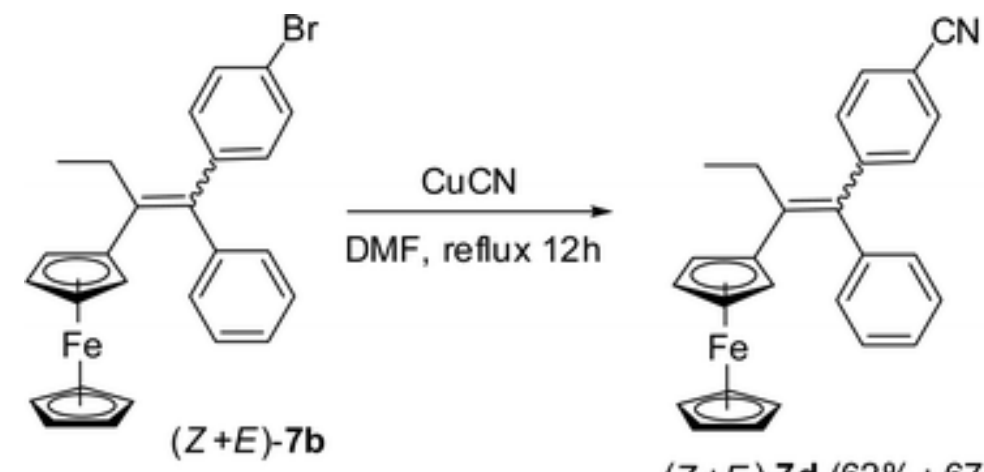

$(Z+E)-7 \mathbf{d}(62 \% ; 67 / 33)$

Scheme 2 Synthesis of the ferrocenyl derivative 7d (in brackets are the yield and ratio of the $Z$ and $E$ isomers).

Interestingly, no isomerisation of the new complexes 7a-d was observed by NMR spectroscopy in $\mathrm{CDCl}_{3}$ after a $3 \mathrm{~d}$ period. This is completely different to what has been observed previously with the ferrocenyl phenol complexes, which possess a labile proton and can isomerise readily, depending on the solvent. ${ }^{22,23}$ 


\subsection{Crystal structures of $(Z)-7 a,(Z)-7 b,(E)-7 c$, and $(E)-7 d$ and $(Z)-7 d$}

Fig. 1 shows ORTEP diagrams of the X-ray structure of the chloro derivative (Z)-7a, the bromo derivative $(Z)-\mathbf{7 b}$, the $\mathrm{CF}_{3}$ derivative $(E)-\mathbf{7 c}$, and the cyano derivatives $(Z)-$ and $(E)-\mathbf{7 d}$. Crystallographic data are given in Table 1. In all cases, the ferrocenyl group is oriented towards the ethyl substituent, thus avoiding potential steric hindrance with its cis-disposed aryl neighbour. Table 2 lists some pertinent bond lengths and angles.

Table 1 Crystallographic information for $(Z)-\mathbf{7 a},(Z)-\mathbf{7 b},(E)-\mathbf{7 c},(Z)-\mathbf{7 d}$, and $(E)-\mathbf{7 d}$
(Z)-7a
$(Z)-7 b$
$(\boldsymbol{E})-7 \mathrm{c}$
(Z)-7d
(E)-7d

\begin{tabular}{|c|c|c|c|c|c|}
\hline Empirical formula & $\mathrm{C}_{26} \mathrm{H}_{23} \mathrm{ClFe}$ & $\mathrm{C}_{26} \mathrm{H}_{23} \mathrm{FeBr}$ & $\mathrm{C}_{27} \mathrm{H}_{23} \mathrm{~F}_{3} \mathrm{Fe}$ & $\mathrm{C}_{27} \mathrm{H}_{23} \mathrm{NFe}$ & $\mathrm{C}_{27} \mathrm{H}_{23} \mathrm{NFe}$ \\
\hline Formula mass & 426.74 & 471.20 & 460.30 & 417.31 & 417.31 \\
\hline$T / \mathrm{K}$ & $100(2)$ & 293(2) & $293(2)$ & $100(2)$ & $100(2)$ \\
\hline$\lambda / \AA$ & 0.71073 & 0.71073 & 0.71073 & 0.71073 & 0.71073 \\
\hline Crystal system & Triclinic & Monoclinic & Triclinic & Triclinic & Triclinic \\
\hline Space group & $P \overline{1}(\# 2)$ & $P 2_{1} / n(\# 14)$ & $P \overline{1}(\# 2)$ & $P \overline{1}(\# 2)$ & $P \overline{1}(\# 2)$ \\
\hline$a / \AA$ & $9.1798(8)$ & $9.455(1)$ & $9.7125(6)$ & $9.321(1)$ & $9.2142(7)$ \\
\hline$b / \AA$ & $10.978(1)$ & $11.086(2)$ & $10.4325(7)$ & $11.135(2)$ & $10.3767(8)$ \\
\hline$c / \AA ̊$ & $11.790(1)$ & 20.771(3) & $12.1883(8)$ & $11.618(2)$ & $11.6810(9)$ \\
\hline$\alpha /^{\circ}$ & $99.195(2)$ & 90 & $101.835(1)$ & $100.243(3)$ & $77.883(1)$ \\
\hline$\beta 1^{\circ}$ & $107.186(2)$ & $98.579(3)$ & $112.708(1)$ & 109.304(2) & $68.208(1)$ \\
\hline$\gamma /{ }^{\circ}$ & $110.096(2)$ & 90 & $90.435(1)$ & $107.291(2)$ & $88.593(1)$ \\
\hline$V / \AA^{3}$ & $1019.7(2)$ & $2152.7(5)$ & $1109.9(1)$ & $1034.3(3)$ & $1012.2(1)$ \\
\hline$Z$ & 2 & 4 & 2 & 2 & 2 \\
\hline$D_{\mathrm{c}} / \mathrm{g} \mathrm{cm}^{-3}$ & 1.390 & 1.454 & 1.377 & 1.340 & 1.369 \\
\hline$\mu / \mathrm{mm}^{-1}$ & 0.879 & 2.565 & 0.715 & 0.741 & 0.758 \\
\hline$F(000)$ & 444 & 960 & 476 & 436 & 436 \\
\hline Crystal size $/ \mathrm{mm}^{3}$ & $\begin{array}{l}0.50 \times 0.40 \times \\
0.10\end{array}$ & $\begin{array}{l}0.70 \times 0.40 \times \\
0.30\end{array}$ & $\begin{array}{l}0.60 \times 0.50 \times \\
0.20\end{array}$ & $\begin{array}{l}0.60 \times 0.40 \times \\
0.05\end{array}$ & $\begin{array}{l}0.80 \times 0.40 \times \\
0.20\end{array}$ \\
\hline
\end{tabular}


$\begin{array}{lllll}(Z)-7 \mathbf{a} & (Z)-7 \mathbf{b} & (E)-7 \mathrm{c} & (Z)-7 \mathrm{~d} & (E)-7 \mathrm{~d}\end{array}$

\begin{tabular}{|c|c|c|c|c|c|}
\hline$\theta$ range for data collection $/^{\circ}$ & $1.89-30.49$ & $1.98-24.17$ & $1.86-26.39$ & $1.95-30.47$ & $1.92-30.50$ \\
\hline \multirow[t]{3}{*}{ Ranges of $h, k, l$} & $-13 \leq h \leq 13$ & $-10 \leq h \leq 10$ & $-12 \leq h \leq 12$ & $-13 \leq h \leq 13$ & $-13 \leq h \leq 13$ \\
\hline & $-15 \leq k \leq 15$ & $-12 \leq k \leq 12$ & $-12 \leq k \leq 13$ & $-15 \leq k \leq 15$ & $-14 \leq k \leq 14$ \\
\hline & $-16 \leq l \leq 16$ & $-23 \leq l \leq 23$ & $-15 \leq l \leq 15$ & $-16 \leq l \leq 16$ & $-16 \leq l \leq 16$ \\
\hline Reflections collected & 22699 & 15297 & 19810 & 22706 & 23932 \\
\hline \multirow[t]{2}{*}{ Independent reflections } & 5865 & 3417 & 4517 & 5916 & 6151 \\
\hline & {$\left[R_{\mathrm{int}}=0.0262\right]$} & {$\left[R_{\mathrm{int}}=0.0226\right]$} & {$\left[R_{\mathrm{int}}=0.0228\right]$} & {$\left[R_{\mathrm{int}}=0.0243\right]$} & {$\left[R_{\mathrm{int}}=0.0245\right]$} \\
\hline $\begin{array}{l}\text { Completeness } \\
29.00^{\circ} \%\end{array}$ & 99.7 & 99.2 & 99.6 & 99.7 & 99.6 \\
\hline Max. and min. transmission & $\begin{array}{l}0.9173 \text { and } \\
0.8053\end{array}$ & $\begin{array}{l}0.5133 \text { and } \\
0.2955\end{array}$ & $\begin{array}{l}0.8702 \text { and } \\
0.7655\end{array}$ & $\begin{array}{l}0.9639 \text { and } \\
0.7930\end{array}$ & $\begin{array}{l}0.8632 \text { and } \\
0.6729\end{array}$ \\
\hline Data/restraints/parameters & $5865 / 0 / 345$ & $3417 / 0 / 254$ & $4517 / 1 / 293$ & $5916 / 0 / 354$ & $6151 / 0 / 354$ \\
\hline Goodness of fit on $F^{2}$ & 1.060 & 1.030 & 1.032 & 1.075 & 1.044 \\
\hline $\begin{array}{l}\text { Final } R / R_{\mathrm{w}} \text { indices } \\
2 \sigma(I)]\end{array}$ & $0.0317 / 0.0808$ & $0.0318 / 0.0780$ & $0.0484 / 0.1314$ & $0.0334 / 0.0864$ & $0.0317 / 0.0823$ \\
\hline Final $R / R_{\mathrm{w}}$ indices (all data) & $0.0354 / 0.0829$ & $0.0388 / 0.0816$ & $0.0522 / 0.1353$ & $0.0361 / 0.0883$ & $0.0346 / 0.0840$ \\
\hline $\begin{array}{l}\text { Largest diffraction peak and } \\
\text { hole/e } \AA^{-3}\end{array}$ & $\begin{array}{l}0.533 \text { and } \\
-0.256\end{array}$ & $\begin{array}{l}0.568 \text { and } \\
-0.424\end{array}$ & $\begin{array}{l}0.554 \text { and } \\
-0.452\end{array}$ & $\begin{array}{l}0.608 \text { and } \\
-0.202\end{array}$ & $\begin{array}{l}0.506 \text { and } \\
-0.263\end{array}$ \\
\hline
\end{tabular}


Table 2 Representative bond distances $(\AA)$ and angles $\left(^{\circ}\right)$

$$
\begin{array}{lllll}
(Z)-7 \mathbf{a} & (Z)-7 \mathbf{b} & (E)-7 \mathrm{c} & (Z)-7 \mathbf{d}^{\mathrm{a}} & (E)-7 \mathrm{~d}
\end{array}
$$

\section{Bond distances/Å}

\begin{tabular}{llllll}
\hline $\mathrm{C} 9-\mathrm{C} 10$ & $1.438(2)$ & $1.419(4)$ & $1.421(4)$ & $1.439(2)$ & $1.435(2)$ \\
$\mathrm{C} 10-\mathrm{C} 11$ & $1.473(2)$ & $1.479(4)$ & $1.474(3)$ & $1.472(2)$ & $1.474(2)$ \\
$\mathrm{C} 11-\mathrm{C} 14$ & $1.357(2)$ & $1.352(4)$ & $1.354(3)$ & $1.357(2)$ & $1.360(2)$ \\
$\mathrm{C} 14-\mathrm{C} 21$ & $1.489(2)$ & $1.494(4)$ & $1.485(3)$ & $1.489(2)$ & $1.490(2)$ \\
$\mathrm{C} 14-\mathrm{C} 15$ & $1.493(2)$ & $1.491(4)$ & $1.492(3)$ & $1.492(2)$ & $1.491(1)$
\end{tabular}

${ }^{\mathrm{a}} \mathrm{C} 22=\mathrm{C} 21$ in the atom numbering scheme for $(Z)-7 \mathbf{d}$.

\begin{tabular}{llllll}
\hline Bond angles $^{\circ}$ & & & & & \\
\hline $\mathrm{C} 10-\mathrm{C} 11-\mathrm{C} 12$ & $115.6(1)$ & $116.9(2)$ & $115.8(2)$ & $115.4(1)$ & $115.82(9)$ \\
$\mathrm{C} 21-\mathrm{C} 14-\mathrm{C} 15$ & $114.4(1)$ & $114.0(2)$ & $113.5(2)$ & $114.2(1)$ & $113.85(9)$ \\
$\mathrm{C} 10-\mathrm{C} 11-\mathrm{C} 14-\mathrm{C} 15$ & $12.0(2)$ & $14.8(4)$ & $-10.9(4)$ & $11.6(2)$ & $-9.4(2)$ \\
$\mathrm{C} 12-\mathrm{C} 11-\mathrm{C} 14-\mathrm{C} 21$ & $13.0(2)$ & $12.1(4)$ & $-12.3(4)$ & $11.9(2)$ & $-11.2(2)$ \\
& & & & & \\
$\mathrm{C} 10-\mathrm{C} 11-\mathrm{C} 14-\mathrm{C} 21$ & $-173.3(1)$ & $-171.3(3)$ & $169.5(2)$ & $-173.6(1)$ & $172.2(1)$
\end{tabular}




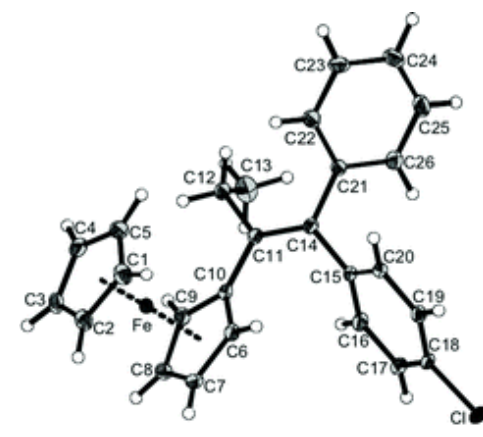

(Z)-7a

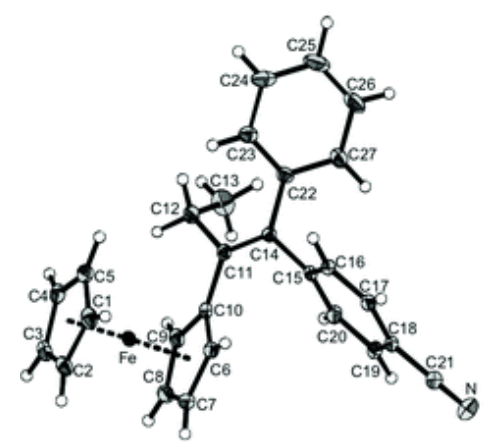

(Z)-7d

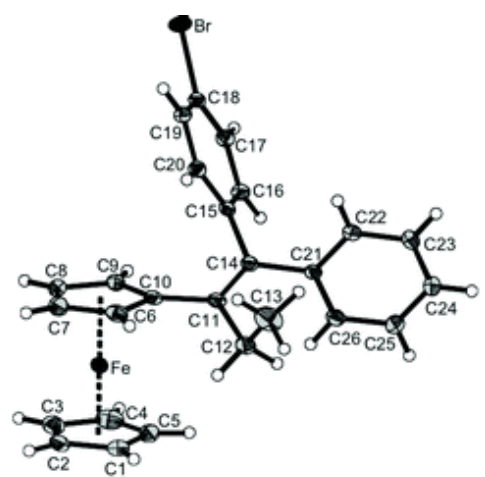

(Z)-7b

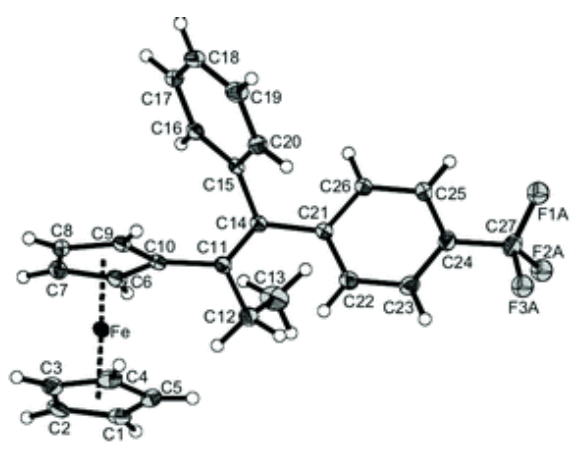

(E)-7c

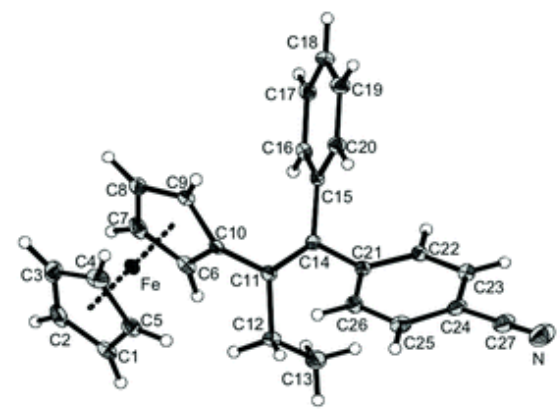

(E)-7d

Fig. 1 ORTEP diagrams of $(Z)-\mathbf{7 a},(Z)-\mathbf{7 b},(E)-\mathbf{7 c},(Z)$ - and $(E)-\mathbf{7 d}$. Thermal ellipsoids are drawn at $50 \%$ probability level (except for $\mathrm{F}$ atoms, at fixed radii). For $(E)-\mathbf{7 c}$, only the fluorine atoms of major occupancy are shown.

These results show that the substitution of the chloro group by bromo, trifluoromethyl or nitrile group does not markedly affect the carbon-carbon bond distances and angles in the molecular framework. However, the molecules are not planar around the alkene, with torsion angles of $12.0^{\circ}$ between the $\mathrm{C} 10-\mathrm{C} 11$ and $\mathrm{C} 14-\mathrm{C} 15$ bonds and $13.0^{\circ}$ between the $\mathrm{C} 12-\mathrm{C} 11$ and $\mathrm{C} 14-\mathrm{C} 21$ bonds for $(Z)-7 \mathbf{a}$. Compound $(E)-7 \mathbf{d}$ manifests the same deformation, but is somewhat closer to planarity.

\subsection{Biological results}

\subsubsection{Determination of the relative binding affinity (RBA) values of the compounds for the two} forms of oestrogen receptor (ER $\alpha$ and $E R \beta)$

The RBA values obtained for the new compounds are given in Table 3. The values found are low $(\leq 0.55 \%)$, considerably lower than that found for the ferrocenyl phenol $\mathbf{3}(4.6 \%)$. This is not surprising, in that the compounds do not possess any groups which can act as strong 
hydrogen bond donors or acceptors, which are the essential interactions that anchor the ligand inside the hydrophobic binding pocket of the oestrogen receptor. Compounds $7 \mathbf{a}, 7 \mathbf{b}, 7 \mathbf{d}$ have RBA values for ER $\alpha$ on the same order of magnitude, while the $\mathrm{CF}_{3}$ derivative $7 \mathbf{c}$, which has the most sterically demanding substituent, has a considerably poorer affinity. This trend is observed in the binding affinities for both ER $\alpha$ and ER $\beta$. Although low, all compounds have non-zero RBA values, and thus would be expected to interact with the ERs.

Table 3 Relative binding affinities values (RBA) for the two isoforms of the receptor (ER $\alpha$ and $\mathrm{ER} \beta$ ) and effect on the growth of hormone dependent (MCF-7) and hormone independent (MDA-MB-231) breast cancer cells

\begin{tabular}{|c|c|c|c|c|c|}
\hline \multirow[b]{2}{*}{ Compounds } & \multirow[b]{2}{*}{$\mathbf{R}$} & \multicolumn{2}{|l|}{$\operatorname{RBA}(\%)^{\mathbf{a}}$} & \multicolumn{2}{|c|}{ Effect on the growth of cells ${ }^{b}$} \\
\hline & & $\mathbf{E R \alpha}$ & ERß & $1 \mu \mathrm{M}$ on MCF-7 & $\begin{array}{l}10 \mu \mathrm{M} \text { on } \mathrm{MDA}-\mathrm{MB}-231\left[\mathrm{IC}_{50}\right. \\
\mu \mathrm{M}]^{\mathrm{c}}\end{array}$ \\
\hline$(Z)-7 \mathbf{a}$ & $\mathrm{Cl}$ & $0.29 \pm 0.01$ & $0.36 \pm 0.04$ & 152 & 83 \\
\hline$(Z)-7 \mathbf{b}$ & $\mathrm{Br}$ & $0.26 \pm 0$ & $0.55 \pm 0.02$ & 153 & 86 \\
\hline$(E)-7 \mathbf{c}$ & $\mathrm{CF}_{3}$ & $0.05 \pm 0.02$ & $0.04 \pm 0.01$ & 127 & 97 \\
\hline$(Z)-7 \mathbf{d}$ & $\mathrm{CN}$ & $0.41 \pm 0.01$ & $0.31 \pm 0.04$ & 133 & $55[11 \mu \mathrm{M}]$ \\
\hline$(E)-7 \mathbf{d}$ & $\mathrm{CN}$ & $0.20 \pm 0.01$ & $0.03 \pm 0.01$ & 148 & $78[60 \mu \mathrm{M}]$ \\
\hline
\end{tabular}

\subsubsection{Effect of 7a-d on the growth of hormone dependent breast cancer MCF-7 cells}

At a concentration of $1 \mu \mathrm{M}$, all compounds $7 \mathbf{a}-\mathbf{d}$ show a significant proliferative effect on the ER+MCF-7 cells (Table 3). This demonstrates that at this concentration and despite their low RBA values they can interact with $\mathrm{ER} \alpha$ and act as oestrogens.

\subsubsection{Effect of 7a-d on the growth of hormone independent breast cancer MDA-MB-231 cells} The effects of $10 \mu \mathrm{M}$ of the compounds on the growth of MDA-MB-231 are reported in Table 3. The halogen complexes (Z)-7a and (Z)-7b show only a modest antiproliferative effect while the $\mathrm{CF}_{3}$ derivative $(E)-7 \mathrm{c}$ has no effect. We have previously hypothesised that the strong antiproliferative effect found for the ferrocenyl complexes 3,5 and $\mathbf{6}$ was associated with the 
presence of protons which can be abstracted to yield quinone-type structure. Lacking such protons complexes 7a-c cannot undergo this type of reaction.

On the contrary, the two nitrile isomers $(Z)$ and $(E)$-7d show a significant antiproliferative effect and interestingly the two isomers behave differently. With an $\mathrm{IC}_{50}$ value of $11 \mu \mathrm{M}$ the $(Z)$ isomer is significantly more cytotoxic than its $(E)$ isomer $\left(\mathrm{IC}_{50}=60 \mu \mathrm{M}\right)$. This is the first time that such a difference is observed in this series and this result can easily be attributed to the lack of isomerisation of the complexes.

\subsection{Molecular modelling}

Molecular docking experiments using the crystal structure of human ER $\alpha$ (hER $\alpha$ ) crystallised with diethylstilbestrol (DES) (pdb erdent), ${ }^{24}$ were performed. Only the amino acids that constitute the wall of the cavity have been retained. The DES molecules were removed from the cavity and replaced successively with the different bio-ligands. Energy minimisation was then carried out using Merck molecular force field (MMFF). All the heavy atoms of the amino acids of the cavity wall were then immobilised and the side chain of His524 was liberated. This allowed the ideal positions of the bio-ligands to be determined. Quantum mechanical semi-empirical PM3 methods were then used to determine the affinity of the bioligands for the cavity. This requires calculation of the energies of bio-ligand cavity group, of the cavity itself, and of the ligand, the latter two in the conformations they had in the molecular assemblies to give the $\Delta_{\mathrm{r}} H^{\circ}$ enthalpy variations of the reactions: bio-ligand + cavity $\rightarrow$ molecular assembly (Table 4). The bio-ligands are shown as compact models, with van der Waals spheres, the amino acids of the cavity wall are shown as sticks. Some important amino acids are labelled (Fig. 2). 
Table 4 Enthalpy variation values $\left(\Delta_{\mathrm{r}} H^{\circ}\right)$ of $7 \mathbf{a}-\mathbf{d}$ docked in $\mathrm{hER} \alpha$

\begin{tabular}{ll} 
Compound & $\boldsymbol{\Delta}_{\mathbf{r}} H^{\circ} / \mathbf{k c a l ~ m o l}^{-1}$ \\
\hline DES & -27.4 \\
$(Z)-7 \mathbf{a}$ & -14.0 \\
$(Z)-7 \mathbf{b}$ & -14.0 \\
$(E)-7 \mathbf{c}$ & -0.6 \\
$(E)-7 \mathbf{d}$ & -1.7 \\
$(Z)-7 d$ & -14.0
\end{tabular}
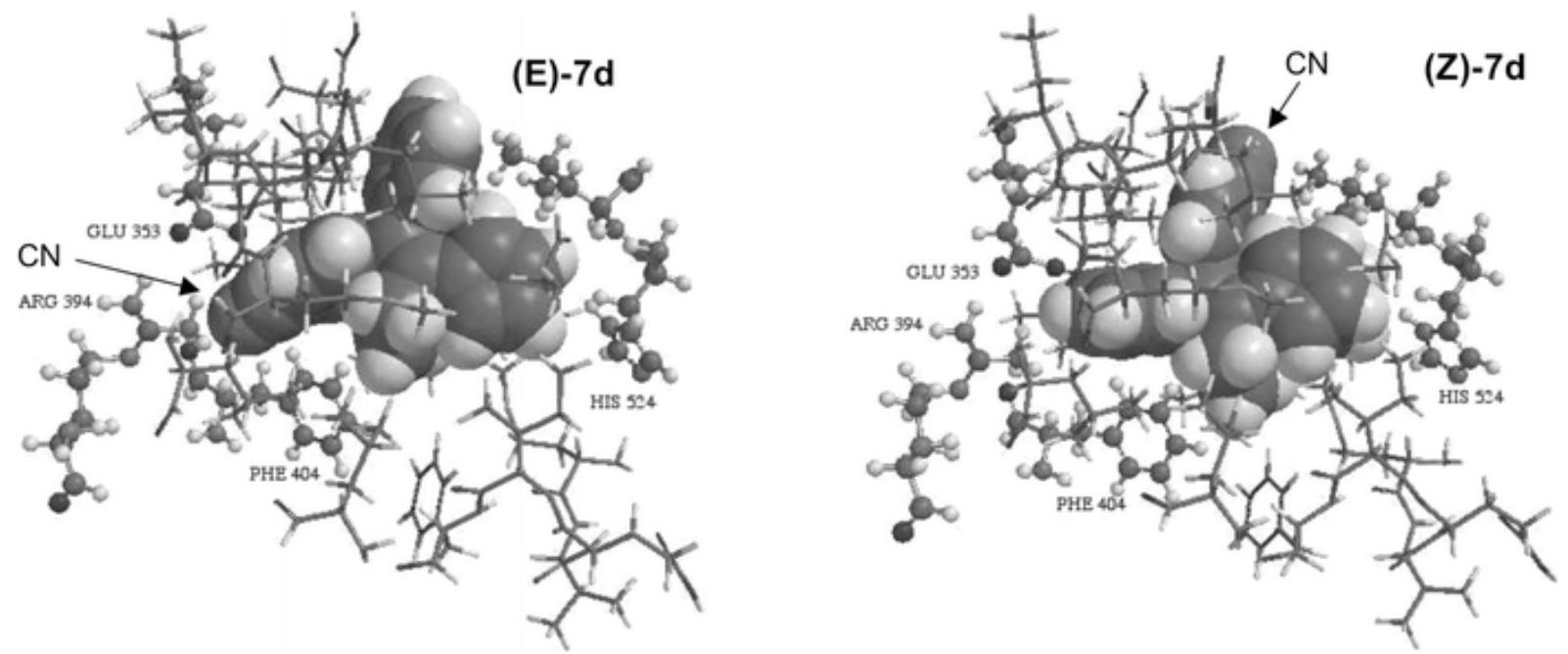

Fig. 2 Molecular modelling representation of (E)-7d (left) and (Z)-7d (right) in the ligand binding domain of the $\mathrm{hER} \alpha$.

For all compounds, binding to the ER is thermodynamically favoured, as evidenced by the negative enthalpy of formation for the ligand-receptor complex. The $Z$ conformation is more favoured than the $E$ conformation for $7 \mathbf{d}\left(\Delta_{\mathrm{r}} H^{\circ}=-14.0\right.$ and $-1.7 \mathrm{kcal} \mathrm{mol}^{-1}$, respectively). This result can be explained by the analysis of the molecular modelling representation of the two isomers represented on Fig. 2. In the case of $(E)-\mathbf{7 d}$, the cyano substituent is located in the place normally occupied by the 3-phenolic group of oestradiol, i.e. in the vicinity of Glu 353 and Arg 394 (in its protonated form). But in contrast to the 3-OH group of oestradiol which can form two hydrogen bonds, one between O and Arg 394 and one between $\mathrm{H}$ and Glu 353, the $\mathrm{N}$ of the $\mathrm{CN}$ substituent can bind only weakly with Arg 394. This observation is consistent with the modest $\Delta_{\mathrm{r}} H^{\circ}$ value found for $(E)-7 \mathbf{d}$. In the case of $(Z)-7 \mathbf{d}$ there is no 
significant anchoring of the molecule with Arg 394. Here, the benzonitrile group is hosted in a pocket located opposite to the $11 \beta$ position of oestradiol and which is known to accommodate bulky substituents. The remaining part of $(Z)-7 \mathbf{d}$ fits perfectly in the hydrophobic binding pocket of the receptor with an anchoring point between the iron of the ferrocenyl and His 524 .

\subsection{Electrochemical results}

Cyclic voltammograms were obtained for all compounds in methanol, and ferrocene redox potentials $\left(E_{1 / 2}\right)$ are given in Table 5. All compounds gave rise to reversible ferricenium/ferrocene couples ranging from $0.47-0.49 \mathrm{~V} v s . \mathrm{Ag} / \mathrm{AgCl}$ with scan rates varying from 0.05 to $2 \mathrm{~V} \mathrm{~s}^{-1}$. No other oxidation features were observed in the potential range of $0-1$ V vs. Ag/AgCl.

Table 5 Comparison of cytotoxicity with electronic parameters for a variety of substituents

\begin{tabular}{|c|c|c|c|c|c|c|c|}
\hline \multirow[b]{2}{*}{ Compound } & \multirow[b]{2}{*}{$\mathbf{R}$} & \multirow{2}{*}{$\begin{array}{l}R^{\mathrm{a}}(\text { resonance } \\
\text { factor) }\end{array}$} & \multirow[b]{2}{*}{ Cytotoxic $^{b}$} & \multicolumn{2}{|c|}{$\begin{array}{l}\text { Cell viability (MDA-MB } \\
231, \% \text { vs. control) }\end{array}$} & \multirow[b]{2}{*}{$E_{1 / 2} / \mathbf{V}$} & \multirow[b]{2}{*}{$\sigma^{\mathrm{a}}$} \\
\hline & & & & $\overline{10 \mu M}$ & $1 \mu \mathrm{M}$ & & \\
\hline 5 & $\mathrm{NH}_{2}$ & -0.74 & $\mathrm{Yes}^{\mathrm{c}}$ & N.d. $(<37)$ & 37 & 0.421 & -0.66 \\
\hline 3 & $\mathrm{OH}$ & -0.70 & $\mathrm{Yes}^{\mathrm{d}}$ & 10 & 67 & 0.433 & -0.37 \\
\hline 6 & $\mathrm{NHC}(\mathrm{O}) \mathrm{Me}$ & -0.31 & $\mathrm{Yes}^{\mathrm{c}}$ & 14 & 26 & 0.451 & 0.00 \\
\hline (Z)-7b & $\mathrm{Br}$ & -0.22 & No & 86 & 93 & 0.470 & 0.23 \\
\hline \multirow[t]{2}{*}{$(Z)-7 \mathbf{a}$} & $\mathrm{Cl}$ & -0.19 & No & 83 & 93 & 0.470 & 0.23 \\
\hline & $\mathrm{H}$ & 0.00 & No & N.d. & 93 & 0.452 & 0.00 \\
\hline (Z)-7d & $\mathrm{CN}$ & 0.15 & Yes & 55 & 91 & 0.492 & 0.66 \\
\hline$(E)-\mathbf{7 d}$ & $\mathrm{CN}$ & 0.15 & Yes & 78 & 96 & 0.482 & 0.66 \\
\hline$(E)-7 \mathbf{c}$ & $\mathrm{CF}_{3}$ & 0.16 & No & 97 & 95 & 0.478 & 0.54 \\
\hline
\end{tabular}

${ }^{\text {a }}$ Values from ref. $16 .{ }^{b}$ A compound is considered as cytotoxic when its cell viability at $10 \mu \mathrm{M}$ on MDA-MB-231 cells is lower than $80 \% .{ }^{c}$ Value from ref. $14 .{ }^{d}$ Value from ref. 7. 


\section{Discussion}

The mechanism proposed to take into account the antiproliferative effects of species based on the 2-ferrocenyl-1,1-diphenyl motif involves the formation of quinoid compounds when protic groups are situated in the para position of one or both of the phenyl rings. ${ }^{12}$ In order to test the validity of this mechanism we wish to (1) examine the biological behaviour of non-protic substituents, and (2) establish a correlation between the electronic constants of the substituents and the observed antiproliferative effects. Our choice for this study was the hormone independent breast cancer cell line MDA-MB-231, which does not contain ER $\alpha$. The cytotoxic effect is therefore not confounded with other parameters such as oestrogenicity.

The Hammett equation and its extensions have traditionally been utilised for the study and the interpretation of numerous organic reactions and their mechanisms. More recently, the analysis of correlations between biological processes and a variety of substituent constants (electronic, lipophilic, steric, inter alia) have been used in multi-factorial quantitative structure-activity relationships (QSAR). An excellent compilation of the inductive and resonance parameters of different substituents has been published by Hansch, Leo and Taft, ${ }^{16}$ which serves as the basis of this analysis. Electronic effects of the substituents are composed of two parts: field/inductive effects $(\sigma)$ and resonance effects $(R) .{ }^{25}$ The obtained values must, however, be considered with caution to take into account solvent effects. This is particularly true in the case of substituents with strong $\pi$-donating effects whereby the formation of transquinoid entities for which the resonance form shown below (Chart 2) can be favoured.

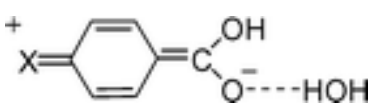

Chart 2

The results for all of the mono-substituted compounds studied up to now, including the new compounds introduced in this report, are shown on Table 5, along with the evaluation of their cytotoxicity observed on MDA-MB-231 cell line and the $R$ and $\sigma$ values of the substituents. At $10^{-6} \mathrm{M}$, all new compounds, as well as the previously reported unsubstituted compound, ${ }^{6}$ show cell proliferation results ranging from $91-96 \%$, although their $R$ constants range from moderately electron donating to electron withdrawing. At this concentration, the greatest difference in cytotoxic effects occurs between those compounds possessing protic substituents $(\mathbf{3}, \mathbf{5}$ and $\mathbf{6})$, and those lacking such substituents. However, at the higher concentration of 
$10^{-5} \mathrm{M}$, a correlation between $R$ and cytotoxic effects begins to appear. The most active compounds are those with the strongest resonance donating substituents. Less active compounds (7a, 7b and 7d) have weakly donating or weakly withdrawing character. Finally, the compound with the strongest resonance withdrawing character (7c) shows the lowest toxicity.

Certain substituents merit a deeper analysis. This is the case with the substituent$\mathrm{NHC}(\mathrm{O}) \mathrm{CH}_{3}$, for which $R$ is -0.31 , a value compatible with an antiproliferative effect. However, the cytotoxic effect is stronger than that predicted by $R$. One possible explanation to account for its similar activity to $\mathbf{5}$ could be in the hydrolysis of the amide to the amine by intercellular amidase enzymes, widely distributed in mammalian cells. ${ }^{26}$ The case of the cyano-substituted compound $\mathbf{7 d}$ is also interesting. The cyano substituent is electronwithdrawing both in terms of field/inductive effects and resonance effects. Thus, 7d would be expected to show very weak or zero activity, this is true for the $E$ isomer, but the $Z$ isomer is significantly more active, with an $\mathrm{IC}_{50}$ value of about $11 \mu \mathrm{M}$. This can be partially explained by examining the resonance structures of the styrene nitrile below (Chart 3), and the observation that protonation of the nitrogen atom further increases $\pi$-bond localisation. ${ }^{27}$ Such protonated distonic (carbene) ions have also been produced in the gas phase. ${ }^{28}$ Conversely, such resonance structures cannot be written for halogen or $\mathrm{CF}_{3}$ substituents. However, the behaviour of 7d is highly dependent on the nature of the isomer, $Z$ or $E$, and thus cannot be explained by electronic effects alone.

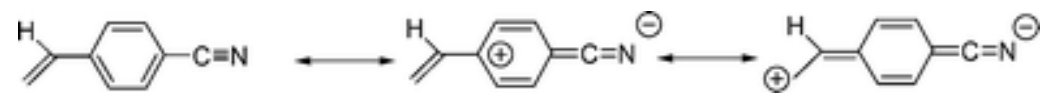

Chart 3 Resonance structures of styrenenitriles.

The redox potentials of the $\mathrm{Fc}^{+} / \mathrm{Fc}$ couples correlate better with $\sigma_{\mathrm{p}}\left(R^{2}=0.98\right)$, than with $R\left(R^{2}=0.80\right)$, Fig. 3. This is in accord with several studies, which have shown the excellent correlation between ferrocene redox potentials and the Hammett-Taft constants of the substituents for phenylferrocenes. ${ }^{29-}$ 33 


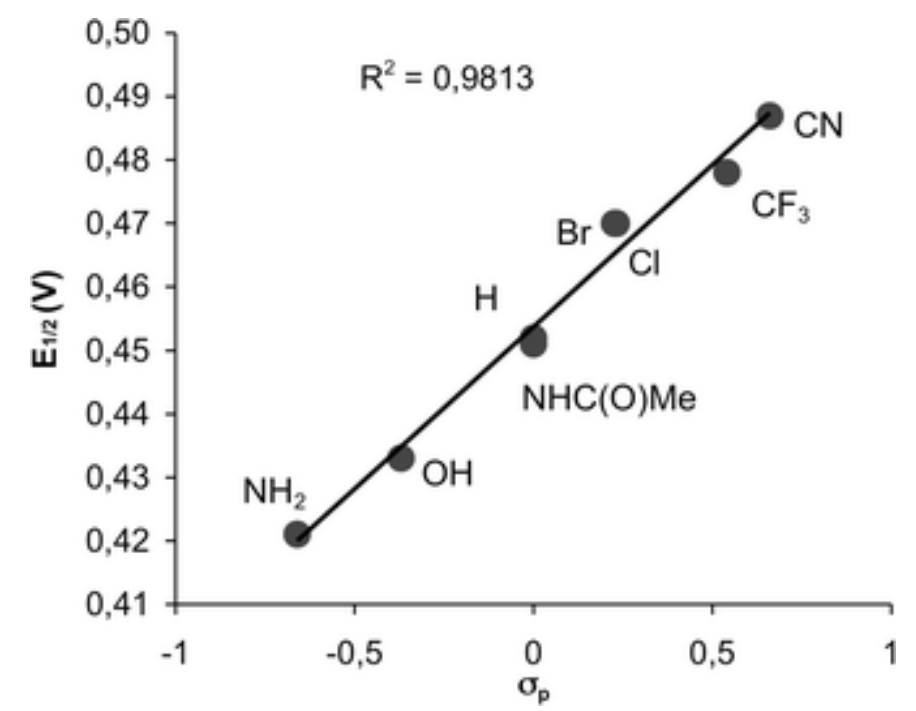

Fig. 3 Plot of $E_{1 / 2}\left(E_{1 / 2}=\left(E^{\mathrm{p}, \mathrm{o}}-E^{\mathrm{p}, \mathrm{r}}\right) / 2\right) v s . \sigma_{\mathrm{p}}$. Values for $\sigma_{\mathrm{p}}$ from ref. 16 .

\section{Conclusions}

We have continued our investigation of the anti-proliferative activity of compounds based on the 2-ferrocenyl-1,1-diphenyl-but-1-ene skeleton by the preparation and study of the $\mathrm{Cl}, \mathrm{Br}$, $\mathrm{CN}$, and $\mathrm{CF}_{3}$ para-substituted derivatives. While possessing only a weak affinity for the oestrogen receptor, each of these compounds act as oestrogens via the ER-mediated pathway. Comparing these new compounds with a series of compounds already in our library, we find that cytotoxicity is primarily dependent on the presence of a protic substituent. This observation is consistent with previous electrochemical experiments which suggest that quinoid structures, formed upon deprotonation of the para-substituent, could be the active species in the cell. Looking more closely, cytotoxicity also weakly correlates with the resonance donating power of the aromatic substituent, except for the special case of the cyano group, which, however enjoys the resonance contribution of a carbene structure, particularly when protonated. Further investigation of molecules possessing nitrile substitution is under way. 


\section{Experimental}

\subsection{General remarks}

The syntheses of all compounds were performed under an argon atmosphere, using standard Schlenk techniques. Anhydrous THF was obtained by distillation from sodium/benzophenone. Thin layer chromatography was performed on silica gel 60 GF254. Infrared spectra were obtained on an IRFT BOMEM Michelson-100 spectrometer equipped with a DTGS detector as a $\mathrm{KBr}$ plate. ${ }^{1} \mathrm{H}$ and ${ }^{13} \mathrm{C}$ NMR spectra were recorded on a $300 \mathrm{MHz}$ Bruker spectrometer. Mass spectrometry was performed with a Nermag R 10-10C spectrometer. Melting points were measured with a Kofler device. Elemental analyses were performed by the microanalysis service of CNRS at Gif sur Yvette. The preparative HPLC separations were performed on a Shimadzu apparatus with a Nucleodur C18 column (length of $25 \mathrm{~cm}$, diameter of $3.2 \mathrm{~cm}$, and particle size of $10 \mu \mathrm{m}$ ) using acetonitrile as an eluent.

\subsection{Synthesis and characterisation of compounds}

\subsubsection{2-Ferrocenyl-1-(4-chlorophenyl)-1-phenyl-but-1-ene, (Z)-7a}

Zinc powder $(3.92 \mathrm{~g}, 60 \mathrm{mmol})$ was suspended in $30 \mathrm{~mL}$ THF at $5-10{ }^{\circ} \mathrm{C}$ in a Schlenk tube under argon. While stirring, titanium tetrachloride $(5.69 \mathrm{~g}, 30 \mathrm{mmol})$ was added slowly via syringe. The reaction mixture was removed from the cold bath and refluxed for $1.5 \mathrm{~h}$ using an oil bath. To the reaction mixture was added $15 \mathrm{~mL}$ of a THF solution containing propionyl ferrocene $(2.42 \mathrm{~g}, 10$ $\mathrm{mmol})$ and 4-chlorobenzophenone (2.17 g, $10 \mathrm{mmol})$, and reflux conditions were maintained for four hours. The reaction mixture was poured into $100 \mathrm{~mL}$ water, acidified with $10 \%$ aqueous $\mathrm{HCl}$ and extracted with $3 \times 100 \mathrm{~mL}$ dichloromethane. The organic layer was washed with $100 \mathrm{~mL}$ of water, dried over magnesium sulfate, filtered, and the solvent was evaporated. The brown oil was first purified on a silica gel column using petroleum ether as an eluent. The fraction at $R_{\mathrm{f}}=0.65$ (pentane) was again purified with preparative HPLC to give $7 \mathbf{a}(2.47 \mathrm{~g}, 58 \%$ yield $)$ as a mixture of $Z$ and $E$ isomers (50:50, calculated from ${ }^{1} \mathrm{H}$ NMR spectrum). The product was recrystallised from acetonitrile to give pure (Z)-7a, identified by single-crystal X-ray diffraction. M.p. $=138{ }^{\circ} \mathrm{C} .{ }^{1} \mathrm{H}$ NMR (300 MHz, $\mathrm{CDCl}_{3}$ ): $\delta 1.04$ (t, $\left.3 \mathrm{H}, J=7.5 \mathrm{~Hz}, \mathrm{CH}_{3}\right) ; 2.60$ (q, $2 \mathrm{H}, J=7.5 \mathrm{~Hz}, \mathrm{CH}_{2}$ ); $3.94\left(\mathrm{t}, 2 \mathrm{H}, \mathrm{C}_{5} \mathrm{H}_{4}\right)$; $4.10\left(\mathrm{t}, 2 \mathrm{H}, \mathrm{C}_{5} \mathrm{H}_{4}\right) ; 4.14\left(\mathrm{~s}, 5 \mathrm{H}, \mathrm{C}_{5} \mathrm{H}_{5}\right) ; 7.01\left(\mathrm{~d}, 2 \mathrm{H}, J=8.7 \mathrm{~Hz}, \mathrm{C}_{6} \mathrm{H}_{4}\right) ; 7.18-7.36\left(\mathrm{~m}, 7 \mathrm{H}, \mathrm{C}_{6} \mathrm{H}_{4}\right.$ and $\mathrm{Ph}) .{ }^{13} \mathrm{C}$ NMR $\left(75.4 \mathrm{MHz}, \mathrm{CDCl}_{3}\right): \delta 15.4\left(\mathrm{CH}_{3}\right) ; 28.1\left(\mathrm{CH}_{2}\right), 68.3$ and $69.4\left(\mathrm{C}_{5} \mathrm{H}_{4}\right) ; 69.2\left(\mathrm{C}_{5} \mathrm{H}_{5}\right) ; 86.4$ $\left(\mathrm{C}_{\mathrm{ip}}, \mathrm{C}_{5} \mathrm{H}_{4}\right) ; 126.4(\mathrm{CH}) ; 128.4(2 \times 2 \mathrm{CH}) ; 129.4(2 \mathrm{CH}) ; 131.4(2 \mathrm{CH}) ; 131.8\left(\mathrm{C}_{\mathrm{q}}\right), 136.6\left(\mathrm{C}_{\mathrm{q}}\right) ; 138.3$ $\left(\mathrm{C}_{\mathrm{q}}\right) ; 143.1\left(\mathrm{C}_{\mathrm{q}}\right)$; and $144.1\left(\mathrm{C}_{\mathrm{q}}\right)\left(\mathrm{C}=\mathrm{C}, \mathrm{C}_{6} \mathrm{H}_{4}\right.$ and $\left.\mathrm{Ph}\right)$. MS (EI, $\left.70 \mathrm{eV}\right): \mathrm{m} / z: 426[\mathrm{M}]^{+}, 397,361[\mathrm{M}-$ 
$\left.\mathrm{C}_{5} \mathrm{H}_{5}\right]^{+}, 345,252,239,121\left[\mathrm{FeC}_{5} \mathrm{H}_{5}\right]^{+}$. Anal. calcd for $\mathrm{C}_{26} \mathrm{H}_{23} \mathrm{ClFe}: \mathrm{C} 73.17, \mathrm{H}$ 5.39, $\mathrm{Cl}$ 8.32; found: $\mathrm{C}$ 73.02, H 5.33, Cl 8.52.

\subsubsection{2-Ferrocenyl-1-(4-bromophenyl)-1-phenyl-but-1-ene, $(Z)$ - or $(E)-7 b$}

The synthesis followed that of 7a using the following reagents: zinc powder $(3.92 \mathrm{~g}, 60$ $\mathrm{mmol})$, titanium chloride (5.69 g, $30 \mathrm{mmol})$, propionyl ferrocene $(2.42 \mathrm{~g}, 10 \mathrm{mmol})$, and 4bromobenzophenone $(2.61 \mathrm{~g}, 10 \mathrm{mmol})$. The organic layer was washed with $100 \mathrm{~mL}$ water, dried over $\mathrm{MgSO}_{4}$, filtered, and the solvent was evaporated. The brown oil was first purified on a silica gel column using petroleum ether as an eluent and then with preparative HPLC to give $7 \mathbf{b}(0.624 \mathrm{~g}, 13 \%$ yield) as a mixture of $Z$ and $E$ isomers (Z-E, $64: 36)$. The product was recrystallised from acetonitrile to give one pure isomer, $(Z)-7 \mathbf{b}$. M.p. $=130{ }^{\circ} \mathrm{C}, R_{\mathrm{f}}=0.65$ (pentane). ${ }^{1} \mathrm{H}$ NMR $\left(300 \mathrm{MHz}, \mathrm{CDCl}_{3}\right): \delta 1.03\left(\mathrm{t}, 3 \mathrm{H}, J=7.3 \mathrm{~Hz}, \mathrm{CH}_{3}\right) ; 2.58(\mathrm{q}, 2 \mathrm{H}, J=7.5$ $\left.\mathrm{Hz}, \mathrm{CH}_{2}\right) ; 3.95$ (s broad, $\left.2 \mathrm{H}, \mathrm{C}_{5} \mathrm{H}_{4}\right) ; 4.15$ (s, 7H, $\left.\mathrm{C}_{5} \mathrm{H}_{4}+\mathrm{C}_{5} \mathrm{H}_{5}\right) ; 6.95(\mathrm{~d}, 2 \mathrm{H}, J=8.3 \mathrm{~Hz}$, $\left.\mathrm{C}_{6} \mathrm{H}_{4}\right) ; 7.15-7.38\left(\mathrm{~m}, 7 \mathrm{H}, \mathrm{C}_{6} \mathrm{H}_{4}\right.$ and $\left.\mathrm{Ph}\right) .{ }^{13} \mathrm{C} \mathrm{NMR}\left(75.4 \mathrm{MHz}, \mathrm{CDCl}_{3}\right): \delta 15.4\left(\mathrm{CH}_{3}\right) ; 28.1$ $\left(\mathrm{CH}_{2}\right) ; 68.4\left(\mathrm{C}_{5} \mathrm{H}_{4}\right) ; 69.4\left(\mathrm{C}_{5} \mathrm{H}_{4}\right) ; 69.3\left(\mathrm{C}_{5} \mathrm{H}_{5}\right) ; 86.5\left(\mathrm{C}_{\mathrm{ip}}, \mathrm{C}_{5} \mathrm{H}_{4}\right) ; 120.0\left(\mathrm{C}_{\mathrm{q}}\right) ; 126.4(\mathrm{CH}) ; 128.4$ $(2 \mathrm{CH}) ; 129.4(2 \mathrm{CH}) ; 131.3(2 \mathrm{CH}) ; 131.7(2 \mathrm{CH}) ; 136.6\left(\mathrm{C}_{\mathrm{q}}\right) ; 138.3\left(\mathrm{C}_{\mathrm{q}}\right) ; 143.6\left(\mathrm{C}_{\mathrm{q}}\right)$; and $144.9\left(\mathrm{C}_{\mathrm{q}}\right)\left(\mathrm{C}=\mathrm{C}, \mathrm{C}_{6} \mathrm{H}_{4}\right.$ and $\left.\mathrm{Ph}\right)$. MS (EI, $\left.70 \mathrm{eV}\right): \mathrm{m} / \mathrm{z}: 470[\mathrm{M}]^{+}$. Anal. calcd for $\mathrm{C}_{26} \mathrm{H}_{23} \mathrm{BrFe}$ : C 66.26, H 4.88, Br 16.96; found: C 66.34, H 4.93, Br 16.76.

\subsubsection{2-Ferrocenyl-1-(4-trifluoromethylphenyl)-1-phenyl-but-1-ene, $(E)-7 \mathrm{c}$}

The synthesis followed that of 7a using the following reagents: zinc powder (3.92 g, $60 \mathrm{mmol}$ ), titanium tetrachloride $(5.69 \mathrm{~g}, 30 \mathrm{mmol})$, propionyl ferrocene $(1.21 \mathrm{~g}, 5 \mathrm{mmol})$, and 4trifluoromethylbenzophenone $(1.25 \mathrm{~g}, 5 \mathrm{mmol})$. The brown oil obtained was first purified on a silica gel column using petroleum ether as an eluent and after with preparative HPLC to give 7c $(0.522 \mathrm{~g}$, $22 \%$ yield) as a mixture of $Z$ and $E$ isomers (Z-E, $45: 55$ ). The product was recrystallised from acetonitrile to give pure (E)-7c. M.p. $=126{ }^{\circ} \mathrm{C} .{ }^{1} \mathrm{H}$ NMR $\left(300 \mathrm{MHz}, \mathrm{CDCl}_{3}\right): \delta 1.07(\mathrm{t}, 3 \mathrm{H}, J=7.5 \mathrm{~Hz}$, $\left.\mathrm{CH}_{3}\right) ; 2.59$ (q, $\left.2 \mathrm{H}, J=7.5 \mathrm{~Hz}, \mathrm{CH}_{2}\right) ; 3.92\left(\mathrm{t}, 2 \mathrm{H}, \mathrm{C}_{5} \mathrm{H}_{4}\right) ; 4.12\left(\mathrm{t}, 2 \mathrm{H}, \mathrm{C}_{5} \mathrm{H}_{4}\right) ; 4.16$ (s, 5H, $\left.\mathrm{C}_{5} \mathrm{H}_{5}\right) ; 7.11$ (d, $2 \mathrm{H}, \mathrm{Ph}) ; 7.25(\mathrm{~m}, 3 \mathrm{H}, \mathrm{Ph}) ; 7.26\left(\mathrm{~d}, 2 \mathrm{H}, J=8.1 \mathrm{~Hz}, \mathrm{C}_{6} \mathrm{H}_{4}\right) ; 7.61\left(\mathrm{~d}, 2 \mathrm{H}, J=8.1 \mathrm{~Hz}, \mathrm{C}_{6} \mathrm{H}_{4}\right) .{ }^{13} \mathrm{C} \mathrm{NMR}$ (75.4 MHz, $\left.\mathrm{CDCl}_{3}\right): \delta 15.4\left(\mathrm{CH}_{3}\right) ; 27.8\left(\mathrm{CH}_{2}\right), 68.4$ and $69.4\left(\mathrm{C}_{5} \mathrm{H}_{4}\right) ; 69.3\left(\mathrm{C}_{5} \mathrm{H}_{5}\right) ; 85.9\left(\mathrm{C}_{\mathrm{ip}}, \mathrm{C}_{5} \mathrm{H}_{4}\right)$; $125.3(\mathrm{CH}) ; 126.5(\mathrm{CH}) ; 128.4(2 \mathrm{CH}) ; 129.7(2 \mathrm{CH}) ; 129.8(2 \mathrm{CH}) ; 136.4\left(\mathrm{C}_{\mathrm{q}}\right) ; 138.8\left(\mathrm{C}_{\mathrm{q}}\right) ; 143.9\left(\mathrm{C}_{\mathrm{q}}\right)$; and $148.3\left(\mathrm{C}_{\mathrm{q}}\right)\left(\mathrm{C}=\mathrm{C}, \mathrm{C}_{6} \mathrm{H}_{4}\right.$ and $\left.\mathrm{Ph}\right)$. MS (EI, $\left.70 \mathrm{eV}\right): \mathrm{m} / z: 460[\mathrm{M}]^{+}, 441,395\left[\mathrm{M}-\mathrm{C}_{5} \mathrm{H}_{5}\right]^{+}, 379,319$, 270, 239, $121\left[\mathrm{FeC}_{5} \mathrm{H}_{5}\right]^{+}$. Anal. calcd for $\mathrm{C}_{27} \mathrm{H}_{23} \mathrm{~F}_{3} \mathrm{Fe}$ : C 70.45, H 5.04, F 12.39; found: C 70.46, H $05.01, \mathrm{~F} 12.21$. 


\subsubsection{2-Ferrocenyl-1-(4-cyanophenyl)-1-phenyl-but-1-ene, (Z)- and (E)-7d}

In a Schlenk tube, $600 \mathrm{mg}(1.27 \mathrm{mmol})$ of $(Z+E)-7 \mathbf{b}$ were dissolved in $15 \mathrm{~mL}$ anhydrous DMF. Copper cyanide (682 mg, $7.62 \mathrm{mmol}$ ), dissolved in $12 \mathrm{~mL}$ anhydrous DMF, was added dropwise and the reaction mixture was heated at reflux for $12 \mathrm{~h}$. The mixture was poured in $20 \mathrm{~mL} 30 \%$ sodium cyanide solution. The product was extracted with diethyl ether $(20 \mathrm{~mL})$. The organic phase was washed with $40 \mathrm{~mL} 10 \%$ sodium cyanide solution, followed by $40 \mathrm{~mL}$ saturated sodium chloride solution, dried over $\mathrm{MgSO}_{4}$, filtered, and the solvent was evaporated. The product was purified on a silica gel column with diethyl ether-petroleum ether $(1: 4)$ as an eluent to give $7 \mathbf{d}$, (372 g, $70 \%$ yield) as a mixture of $Z$ and $E$ isomers $(67: 33), R_{\mathrm{f}}=0.6$ (diethyl ether-petroleum ether $1: 4$ ). The two isomers were separated by preparative HPLC (acetonitrile-water $80: 20$ ). Minor isomer ( $E$ isomer identified by X-ray crystallography): m.p. $192{ }^{\circ} \mathrm{C},{ }^{1} \mathrm{H}$ NMR $\left(300 \mathrm{MHz}, \mathrm{CDCl}_{3}\right): \delta 1.02$ (t, 3H, $J=7.5$ $\left.\mathrm{Hz}, \mathrm{CH}_{3}\right), 2.55$ (q, $\left.2 \mathrm{H}, J=7.5 \mathrm{~Hz}, \mathrm{CH}_{2}\right) ; 4.02\left(\mathrm{~s}, 2 \mathrm{H}, \mathrm{C}_{5} \mathrm{H}_{4}\right) ; 4.11\left(\mathrm{~s}, 7 \mathrm{H}, \mathrm{C}_{5} \mathrm{H}_{4}+\mathrm{C}_{5} \mathrm{H}_{5}\right) ; 7.06$ (d, $2 \mathrm{H}, J=6.3 \mathrm{~Hz}, \mathrm{Ph}), 7.21(\mathrm{~m}, 3 \mathrm{H}, \mathrm{Ph}), 7.32\left(\mathrm{~d}, 2 \mathrm{H}, J=8.3 \mathrm{~Hz}, \mathrm{C}_{6} \mathrm{H}_{4}\right), 7.62(\mathrm{~d}, 2 \mathrm{H}, J=8.3 \mathrm{~Hz}$, $\left.\mathrm{C}_{6} \mathrm{H}_{4}\right) .{ }^{13} \mathrm{C}$ NMR $\left(75.4 \mathrm{MHz}, \mathrm{CDCl}_{3}\right): \delta 15.4\left(\mathrm{CH}_{3}\right) ; 27.8\left(\mathrm{CH}_{2}\right) ; 68.6\left(\mathrm{C}_{5} \mathrm{H}_{4}\right) ; 69.6\left(\mathrm{C}_{5} \mathrm{H}_{4}\right) ; 69.5$ $\left(\mathrm{C}_{5} \mathrm{H}_{5}\right) ; 85.7\left(\mathrm{C}_{\mathrm{ip}}, \mathrm{C}_{5} \mathrm{H}_{4}\right) ; 109.9(\mathrm{Cq}, C-\mathrm{CN}) ; 119.9(\mathrm{CN}) ; 126.7(\mathrm{CH}) ; 128.5(2 \mathrm{CH}) ; 129.9(2 \mathrm{CH})$; $130.2(2 \mathrm{CH}) ; 132.2(2 \mathrm{CH}) ; 136.0\left(\mathrm{C}_{\mathrm{q}}\right) ; 139.5\left(\mathrm{C}_{\mathrm{q}}\right) ; 143.5\left(\mathrm{C}_{\mathrm{q}}\right)$; and $149.4\left(\mathrm{C}_{\mathrm{q}}\right)\left(\mathrm{C}=\mathrm{C}, \mathrm{C}_{6} \mathrm{H}_{4}\right.$ and $\left.\mathrm{Ph}\right)$. MS (EI, $70 \mathrm{eV}$ ): $\mathrm{m} / z: 417[\mathrm{M}]^{+}$. Anal. calcd for $\mathrm{C}_{27} \mathrm{H}_{23} \mathrm{FeN}$ : C 77.70, H 5.52, N 3.36; found: $\mathrm{C} 77.28$, H 5.42, N 3.27.

Major isomer $\left(Z\right.$ isomer): m.p. $=142{ }^{\circ} \mathrm{C},{ }^{1} \mathrm{H}$ NMR $\left(300 \mathrm{MHz}, \mathrm{CDCl}_{3}\right): \delta 1.10(\mathrm{t}, 3 \mathrm{H}, J=$ $\left.7.5 \mathrm{~Hz}, \mathrm{CH}_{3}\right), 2.71\left(\mathrm{q}, 2 \mathrm{H}, J=7.5 \mathrm{~Hz}, \mathrm{CH}_{2}\right) ; 3.99\left(\mathrm{t}, 2 \mathrm{H}, \mathrm{C}_{5} \mathrm{H}_{4}\right) ; 4.23\left(\mathrm{~s}+\mathrm{t}, 7 \mathrm{H}, \mathrm{C}_{5} \mathrm{H}_{4}+\right.$ $\mathrm{C}_{5} \mathrm{H}_{5}$ ); 7.23 (d, 2H, $\mathrm{C}_{6} \mathrm{H}_{4}$ or $\mathrm{Ph}$ ); 7.27 (d, 2H, $\mathrm{C}_{6} \mathrm{H}_{4}$ or $\mathrm{Ph}$ ); 7.40 (m, 3H, $\mathrm{C}_{6} \mathrm{H}_{4}+\mathrm{Ph}$ or $\mathrm{Ph}$ ); $7.54\left(\mathrm{~d}, 2 \mathrm{H}, J=7.5 \mathrm{~Hz}, \mathrm{C}_{6} \mathrm{H}_{4}\right) .{ }^{13} \mathrm{C} \mathrm{NMR}\left(75.4 \mathrm{MHz}, \mathrm{CDCl}_{3}\right): \delta 15.4\left(\mathrm{CH}_{3}\right) ; 28.6\left(\mathrm{CH}_{2}\right) ; 68.7$ $\left(\mathrm{C}_{5} \mathrm{H}_{4}\right) ; 69.5\left(\mathrm{C}_{5} \mathrm{H}_{4}\right) ; 69.47\left(\mathrm{C}_{5} \mathrm{H}_{5}\right) ; 86.4\left(\mathrm{C}_{\mathrm{ip}}, \mathrm{C}_{5} \mathrm{H}_{4}\right) ; 109.5(\mathrm{Cq}, C-\mathrm{CN}) ; 119.2(\mathrm{CN}) ; 126.8$ $(\mathrm{CH}) ; 128.6(2 \mathrm{CH}) ; 129.6(2 \mathrm{CH}) ; 131.0(2 \mathrm{CH}) ; 131.9(2 \mathrm{CH}) ; 136.2\left(\mathrm{C}_{\mathrm{q}}\right) ; 140.4\left(\mathrm{C}_{\mathrm{q}}\right) ; 143.2$ $\left(\mathrm{C}_{\mathrm{q}}\right)$; and $149.6\left(\mathrm{C}_{\mathrm{q}}\right)\left(\mathrm{C}=\mathrm{C}, \mathrm{C}_{6} \mathrm{H}_{4}\right.$ and $\left.\mathrm{Ph}\right)$. MS (EI, $\left.70 \mathrm{eV}\right): \mathrm{m} / z: 417[\mathrm{M}]^{+}, 352[\mathrm{M}-\mathrm{Cp}]^{+}$, 336, $121[\mathrm{CpFe}]^{+}$. Anal. calcd for $\mathrm{C}_{27} \mathrm{H}_{23} \mathrm{FeN}$ : C 77.70, H 5.52, N 3.36; found: C 77.28, $\mathrm{H}$ $5.41, \mathrm{~N} 3.14$.

\subsection{X-Ray measurements for $(Z)-7 \mathrm{a},(Z)-7 \mathrm{~b},(E)-7 \mathrm{c},(E)-7 \mathrm{~d}$ and $(Z)-7 \mathrm{~d}$}

Crystal data were collected using a Bruker SMART APEX CCD area detector diffractometer, and are listed in Table 1. A full sphere of the reciprocal space was scanned by phi-omega scans. Pseudo-empirical absorption correction based on redundant reflections was performed by the program SADABS. ${ }^{34}$ The structures were solved by direct methods using SHELXS$97^{35}$ and refined by full-matrix least-squares on $F^{2}$ for all data using SHELXL-97. ${ }^{36}$ In (Z)-7a, $(E)-7 \mathbf{d}$ and $(Z)-7 \mathbf{d}$ all hydrogen atoms were located in the difference Fourier map and allowed 
to refine freely with isotropic thermal displacement factors. All other hydrogen atoms were added at calculated positions and refined using a riding model. Their isotropic displacement parameters were fixed to 1.2 times (1.5 times for methyl groups) the equivalent isotropic displacement parameters of the carbon atom the $\mathrm{H}$-atom is attached to. Anisotropic temperature factors were used for all non-hydrogen atoms, except the disordered fluorine atoms in $(E)-7 \mathbf{c}$, which were left isotropic.

\subsection{Biochemistry}

\subsubsection{Materials}

Stock solutions $\left(1 \times 10^{-3} \mathrm{M}\right)$ of the compounds to be tested were prepared in DMSO and were kept at $4{ }^{\circ} \mathrm{C}$ in the dark; under these conditions they are stable for at least two months. Serial dilutions in ethanol were prepared just prior to use. Dulbecco's modified eagle medium (DMEM) with phenol red/Glutamax I, Dulbecco's modified eagle medium (DMEM) without phenol red, Glutamax I and foetal bovine serum (FBS) were purchased from Gibco; oestradiol from Sigma. MCF-7 and MDA-MB-231 cells were obtained from the Human Tumour Cell Bank. Sheep uteri weighing approximately $7 \mathrm{~g}$ were obtained from the slaughterhouse at Mantes-la-Jolie, France. They were immediately frozen and kept in liquid nitrogen prior to use.

\subsubsection{Determination of the relative binding affinity (RBA) of the compounds for ER $\alpha$ and ER}

RBA values were measured on ER $\alpha$ from lamb uterine cytosol and on ER $\beta$ purchased from Pan Vera (Madison, WI, USA). Sheep uterine cytosol prepared in buffer A (0.05 M TrisHCL, $0.25 \mathrm{M}$ sucrose, $0.1 \% \beta$-mercaptoethanol, $\mathrm{pH} 7.4$ at $25^{\circ} \mathrm{C}$ ) as previously described was used as a source of ER $\alpha{ }^{37}$ For ER $\beta, 10 \mu \mathrm{L}$ of the solution containing $3500 \mathrm{pmol} \mathrm{mL}^{-1}$ were added to $16 \mathrm{~mL}$ of buffer $\mathrm{B}$ (10\% glycerol, $50 \mathrm{mM}$ Bis-Tris-Propane $\mathrm{pH}$ 9, $400 \mathrm{mM} \mathrm{KCl,} 2$ mM DTT, $1 \mathrm{mM}$ EDTA, 0.1\% BSA) in a silanised flask. Aliquots (200 $\mu \mathrm{L})$ of ER $\alpha$ in glass tubes or ER $\beta$ in polypropylene tubes were incubated for $3 \mathrm{~h}$ at $0{ }^{\circ} \mathrm{C}$ with $\left[6,7-{ }^{3} \mathrm{H}\right]$ - estradiol $(2$ $\times 10^{-9} \mathrm{M}$, specific activity $1.62 \mathrm{TBq}^{\mathrm{mmol}}{ }^{-1}$, NEN Life Science, Boston MA) in the presence of nine concentrations of the hormones to be tested. At the end of the incubation period, the free and bound fractions of the tracer were separated by protamine sulfate precipitation. The percentage reduction in binding of $\left[{ }^{3} \mathrm{H}\right]$-oestradiol (Y) was calculated using the logit transformation of $\mathrm{Y}(\operatorname{logit} \mathrm{Y}: \ln [\mathrm{y} / 1-\mathrm{Y}]$ versus the $\log$ of the mass of the competing steroid. 
The concentration of unlabelled steroid required to displace $50 \%$ of the bound $\left[{ }^{3} \mathrm{H}\right]$-oestradiol was calculated for each steroid tested, and the results expressed as RBA. The RBA value of oestradiol is by definition equal to $100 \%$.

\subsubsection{Culture conditions}

Cells were maintained in a monolayer culture in DMEM with phenol red/Glutamax I supplemented with $9 \%$ fetal bovine serum at $37{ }^{\circ} \mathrm{C}$ in a $5 \% \mathrm{CO}_{2} /$ air-humidified incubator. For the proliferation assays, MCF-7 and MDA-MB-231 cells were plated in $1 \mathrm{~mL}$ of DMEM without phenol red, supplemented with $9 \%$ decomplemented and hormone-depleted fetal bovine serum, $0.9 \%$ kanamycin, $0.9 \%$ Glutamax I and incubated. The following day $\left(\mathrm{D}_{0}\right), 1$ $\mathrm{mL}$ of the same medium containing the compounds to be tested was added to the plates. After $3 \mathrm{~d}$ (D3), the incubation medium was removed and $2 \mathrm{~mL}$ of the fresh medium containing the compounds was added. After $5 \mathrm{~d}$ the total protein content of the plate was analysed as follows: cell monolayers were fixed for $1 \mathrm{~h}$ at room temperature with methylene blue $(1 \mathrm{mg}$ $\mathrm{mL}^{-1}$ in $50: 50$ water-MeOH mixture), then washed with water. After addition of $\mathrm{HCl}(0.1$ $\mathrm{M}, 2 \mathrm{~mL}$ ), the plate was incubated for $1 \mathrm{~h}$ at $37^{\circ} \mathrm{C}$ and then the absorbance of each well (6 wells for each concentration) was measured at $655 \mathrm{~nm}$ with a Biorad spectrophotometer. The results are expressed as the percentage of proteins versus the control.

\subsection{Modelling studies}

Molecular modelling studies were carried out using the programs Spartan, Trident and Odyssey. $^{38}$

\subsection{Electrochemistry}

Cyclic voltammograms (CVs) were obtained using a three electrode cell with a $0.5 \mathrm{~mm} \mathrm{Pt}$ working electrode, stainless steel rod counter electrode, and $\mathrm{Ag} / \mathrm{AgCl}$ ethanol reference electrode, with an $\mu$-Autolab 3 potentiostat driven by GPES software (General Purpose Electrochemical System, v. 4.8, EcoChemie B.V., Utrecht, the Netherlands.) Solutions consisted of $10 \mathrm{~mL} \mathrm{MeOH}$, approximately $1 \mathrm{mM}$ analyte, and $0.1 \mathrm{M} \mathrm{TBABF}_{4}$ supporting electrolyte. 


\section{Acknowledgements}

The authors thank the Agence Nationale de la Recherche for financial support ( $\mathrm{N}^{\circ}$ ANR-06BLAN-0384-01, "FerVect").

\section{References}

1 W. H. Ang, A. D. Luca, C. Chapuis-Bernasconi, L. Juillerat-Jeanneret, M. L. Bello and P. J. Dyson, ChemMedChem, 2007, 2, 1799-1806.

2 C. A. Vock, W. H. Ang, C. Scolaro, A. D. Phillips, L. Lagopoulos, L. Juillerat-Jeanneret, G. Sava, R. Scopelliti and P. J. Dyson, J. Med. Chem., 2007, 50, 2166-2175.

3 M. A. Jakupec, M. Galanski and B. K. Keppler, Rev. Physiol. Biochem. Pharmacol., 2003, 146, $1-53$.

4 A. Nguyen, A. Vessières, E. A. Hillard, S. Top, P. Pigeon and G. Jaouen, Chimia, 2007, 61, 716724.

5 A. Vessières, S. Top, P. Pigeon, E. A. Hillard, L. Boubeker, D. Spera and G. Jaouen, J. Med. Chem., 2005, 48, 3937-3940.

6 A. Vessières, D. Spera, S. Top, B. Misterkiewicz, J. M. Heldt, E. A. Hillard, M. Huché, M. A. Plamont, E. Napolitano, R. Fiaschi and G. Jaouen, ChemMedChem, 2006, 1, 1275-1281.

7 E. A. Hillard, P. Pigeon, A. Vessières, C. Amatore and G. Jaouen, Dalton Trans., 2007, 50735081.

8 G. Jaouen, S. Top, A. Vessières, G. Leclercq and M. J. McGlinchey, Curr. Med. Chem., 2004, 11, 2505-2517.

9 J. B. Heilmann, E. A. Hillard, M.-A. Plamont, P. Pigeon, M. Bolte, G. Jaouen and A. Vessières, J. Organomet. Chem., 2008, 693, 1716-1722.

10 A. Vessières, S. Top, W. Beck, E. A. Hillard and G. Jaouen, Dalton Trans., 2006, 4, 529-541.

11 S. Top, A. Vessières, C. Cabestaing, I. Laios, G. Leclercq, C. Provot and G. Jaouen, J. Organomet. Chem., 2001, 637, 500-506.

12 E. A. Hillard, A. Vessières, L. Thouin, G. Jaouen and C. Amatore, Angew. Chem., Int. Ed., 2006, 45, 285-290.

13 S. J. Dougan, A. Habtemariam, S. E. McHale, S. Parsons and P. J. Sadler, Proc. Natl. Acad. Sci. U. S. A., 2008, 105, 11628-11633. 
14 P. Pigeon, S. Top, O. Zekri, E. A. Hillard, A. Vessières, M.-A. Plamont, E. Labbé, O. Buriez, M. Huché, S. Boutamine, C. Amatore and G. Jaouen, J. Organomet. Chem., 2009, DOI: 10.1016/ j.jorganchem.2008.11.035.

15 L. P. Hammett, J. Am. Chem. Soc., 1937, 59, 96-103.

16 C. Hansch, A. Leo and R. W. Taft, Chem. Rev., 1991, 97, 165-195.

17 J. E. McMurry and M. P. Fleming, J. Am. Chem. Soc., 1974, 96, 4708-4709.

18 A. Fürstner and B. Bogdanovic, Angew. Chem., Int. Ed. Engl., 1996, 35, 2442-2469.

19 B. E. Kahn and R. D. Rieke, Chem. Rev., 1988, 88, 733-745.

20 J. E. McMurry and L. R. Krepski, J. Org. Chem., 1976, 41, 3929-3930.

21 G. Jaouen, S. Top, A. Vessières, G. Leclercq, J. Quivy, L. Jin and A. Croisy, C. R. Acad. Sci. Paris, 2000, Série IIc, 89-93.

22 S. Top, A. Vessières, G. Leclercq, J. Quivy, J. Tang, J. Vaissermann, M. Huché and G. Jaouen, Chem.-Eur. J., 2003, 9, 5223-5236.

23 A. Nguyen, S. Top, P. Pigeon, A. Vessières, E. A. Hillard, M.-A. Plamont, M. Huché, C. Rigamonti and G. Jaouen, Chem.-Eur. J., 2009, 15, 684-696.

24 A. K. Shiau, D. Barstad, P. M. Loria, L. Cheng, P. J. Kushner, D. A. Agard and G. L. Greene, Cell, 1998, 95, 927-937.

25 J. D. Roberts and J. W. T. Moreland, J. Am. Chem. Soc., 1953, 75, 2167-2173.

26 K. Sakano, S. Oikawa, Y. Hiraku and S. Kawanishi, Chem.-Biol. Interact., 2004, 149, 51-59.

27 M. Eckert-Maksić, M. Hodošček, D. Kovaček, Z. B. Maksić and M. Pimorac, J. Mol. Struct. (THEOCHEM), 1997, 417, 131-143.

28 R. Fammang, M. Barbieux-Flammang, E. Gualano, P. Gerbaux, H. T. Le, M. T. Nguyen, F. Turecek and S. Vivekanada, J. Phys. Chem. A, 2001, 105, 8579-8587.

29 T. Bobula, J. Hudlicky, P. Novák, R. Gyepes, I. Císarova, P. Štěpnička and M. Kotora, Eur. J. Inorg. Chem., 2008, 3911-3920.

30 G. L. K. Hoh, W. E. McEwen and J. Kleinberg, J. Am. Chem. Soc., 1961, 83, 3949-3953.

31 W. F. Little, C. N. Reilley, J. D. Johnson, K. N. Lynn and A. P. Sanders, J. Am. Chem. Soc., 1964, 86, 1376-1381. 
32 W. F. Little, C. N. Reilley, J. D. Johnson and A. P. Sanders, J. Am. Chem. Soc., 1964, 86, 13821386.

33 S. Lu, V. V. Strelets, M. F. Ryan, W. J. Pietro and A. B. P. Lever, Inorg. Chem., 1996, 35, 10131023.

34 G. M. Sheldrick, SADABS, Bruker AXS Inc., Madison, WI, 53711, 2000.

35 G. M. Sheldrick, SHELXS-97, University of Göttingen, 1997.

36 G. M. Sheldrick, SHELXL-97, University of Göttingen, 1997.

37 A. Vessières, S. Top, A. A. Ismail, I. S. Butler, M. Loüer and G. Jaouen, Biochemistry, 1988, 27, $6659-6666$.

38 Spartan, Trident, Odyssey, Wavefunction Inc., Irvine, CA, 92612. 